\title{
Total Tear IgE Levels Correlate with Allergenic and Irritating Environmental Exposures in Individuals with Dry Eye
}

\author{
Harrison Dermer ${ }^{1}$, Despoina Theotoka ${ }^{2}{ }^{\circledR}$, Charity J. Lee ${ }^{1}$, Priyanka Chhadva ${ }^{3}$, \\ Abigail S. Hackam ${ }^{2}$, Anat Galor ${ }^{2, *}$ and Naresh Kumar ${ }^{4}$ \\ 1 Miller School of Medicine, University of Miami, Miami, FL 33136, USA; hid7@med.miami.edu (H.D.); \\ charity.lee513@gmail.com (C.J.L.) \\ 2 Bascom Palmer Eye Institute, University of Miami, Miami, FL 33136, USA; dxt412@miami.edu (D.T.); \\ ahackam@med.miami.edu (A.S.H.) \\ 3 Department of Ophthalmology, Illinois Eye and Ear Infirmary, University of Illinois, Chicago, IL 60612, USA; \\ pchhadva7@gmail.com \\ 4 Department of Public Health Sciences, University of Miami, Miami, FL 33136, USA; \\ nkumar@med.miami.edu \\ * Correspondence: agalor@med.miami.edu; Tel.: +1-305-575-7000
}

Received: 6 August 2019; Accepted: 2 October 2019; Published: 4 October 2019

\begin{abstract}
Dry eye (DE) and allergic conjunctivitis may present similarly, and it remains unclear whether some individuals have an underlying allergic component to their DE. To better understand this relationship, we performed a cross-sectional study in 75 individuals with DE symptoms and/or signs. Immunoglobulin $\mathrm{E}$ ( $\mathrm{IgE}$ ) levels in tear samples were quantified and home environmental exposures assessed via standardized survey. Tears were collected by Schirmer strip, and total tear IgE levels were quantified using enzyme-linked immunosorbent assay (ELISA). Data were analyzed using descriptive statistics and linear and logistic regressions. The main outcome measures were total tear IgE levels and their association with environmental exposures. The mean age of the subjects was $66.2 \pm 7.8$ years. Sixty-two individuals had dry eye symptoms (Dry Eye Questionnaire-5 $\geq 6$ ), and 75 had one or more signs of DE. Detectable total tear IgE levels were observed in $76 \%$ of subjects, and $17.3 \%$ had high levels (>1 ng/mL). Individuals with exposure to pet(s) (odds ratio (OR) 11.5, $p=0.002$ ) and smoke (OR 38.6, $p=0.008$ ) at home were more likely to have high IgE levels compared to those not exposed. Individuals with tears collected during spring or summer were 3.9 times $(p=0.028)$ more likely to have high IgE compared to those sampled at other times of year. Subjects born in the US were 3.45 times $(p=0.010)$ more likely to have high IgE compared to individuals born outside the US. To conclude, a majority of individuals with DE symptoms and/or signs had detectable IgE levels in their tears. High tear IgE levels were correlated with allergy season and exposures in the home linked with allergy.
\end{abstract}

Keywords: IgE; allergies; environment; pet dander; smoking

\section{Introduction}

Dry eye (DE) is a multifactorial condition broadly defined by inflammatory and/or neurosensory changes at the ocular surface, accompanied by derangements of the tear-film [1]. Affected individuals present with symptoms of ocular irritation, dryness, discomfort, or foreign body sensation [2] Many risk factors have been identified in DE, including internal factors such as thyroid disease, and diabetes, and external factors such as medications (e.g., diuretics, antihistamines), surgery, and environmental exposures [3]. Dry eye impacts more than 16 million Americans [4], and up to 30\% of people over fifty 
years of age worldwide [5], and negatively impacts quality of life [3,6]. Allergic Conjunctivitis (AC) is a hypersensitivity disorder that is considered distinct from DE [7-9]. However, the two entities have overlapping features that include shared symptoms (discomfort and itching [10]) and signs (bulbar hyperemia and ocular surface inflammation [11-14]). Given this overlap, a question remains whether some individuals diagnosed with DE have an underlying sub-clinical component of allergy [15]. Data to support this hypothesis include the reported seasonal variation of $\mathrm{DE}$, with increased symptom severity in spring, correlating with maximal pollen levels $[16,17]$. Furthermore, environmental conditions and exposures known to impact AC $[18,19]$, including humidity, dust mites, and tobacco smoke have also been shown to impact DE $[20,21]$. Determining which factors contribute to DE in an individual patient is crucial for the delivery of precision medicine. As such, an objective marker is needed to identify when DE has an allergic component.

Immunoglobulin E (IgE) is an antibody that plays a critical role in type 1 hypersensitivity reactions and has been used as a biomarker to assist in the diagnosis of allergic disease [22,23]. Total and allergen-specific tear IgE levels have been studied in relation to AC [24], but not in relation to DE. To bridge this knowledge gap, we investigated the frequency of detectable tear IgE levels in individuals with DE symptoms and/or signs but without a diagnosis of AC. Furthermore, we evaluated which factors were associated with high total tear IgE levels, focusing on environmental conditions and exposures associated with allergy. We hypothesized that allergenic or irritating exposures in the home would associate with high IgE levels in our cohort.

\section{Experimental Section}

Study Population: Male and female subjects were prospectively recruited from the Miami VA Medical Center eye clinic between October 2010 and December 2011. Written informed consent was obtained from all subjects after verbal explanation of the nature and possible consequences of the study.

Inclusion criteria included the presence of DE symptoms and/or signs, grossly normal eyelid and corneal anatomy, no evidence of ocular surface pathology beyond DE (e.g., corneal edema, pterygium), and no characteristic findings of AC (e.g., chemosis, conjunctival fibrosis). Based on review of the medical record, patients were excluded from participation if they had ocular or systemic conditions that could confound DE, including contact lens wear, a history of refractive surgery, use of ocular medications except for artificial tears, active external ocular pathology, cataract surgery in the last 6 months, or a history of glaucoma or retinal surgery. Systemically, individuals with human immunodeficiency virus, sarcoidosis, Sjögren's, graft-versus host disease, collagen vascular disease, or primary immunodeficiency with elevated serum IgE (e.g., Job syndrome, Wiskott-Aldrich syndrome) were excluded. Subjects with a history of omalizumab use, symptomatic AC, or specific allergic sensitization confirmed by skin or conjunctival provocation test or serum-specific IgE were also excluded.

The Miami VA institutional review board approved the examination of patients for this study, which was conducted in accordance with the principles of the Declaration of Helsinki (IRB Protocol \#3011.02) and complied with the requirements of the United States Health Insurance Portability and Accountability Act.

Clinical assessment and home environment survey: Each individual filled out a standardized questionnaire regarding DE symptoms (Dry Eye Questionnaire-5, DEQ5: score 0-22 [25]) and an additional survey of exposures associated with allergy (e.g., pets, carpets) or the aggravation of allergy (tobacco smoke) (Appendix A). All individuals underwent an ocular surface exam, which included, in the order performed: tear osmolarity (TearLab Osmolarity System, TearLab, San Diego, CA, USA) (once in each eye), tear evaporation measured as tear break up time (TBUT) $(5 \mu \mathrm{L}$ fluorescein instilled in the superior conjunctiva, time measured in seconds until the first black spot appeared in the tear film, two measurements taken with $5 \mathrm{~s}$ blink interval between measurements and averaged), assessment of corneal epithelial cell disruption measured by staining with fluorescein (Bron scale, 0-4 scale [26]), and assessment of tear production via Schirmer's test with anesthesia (measured as millimeters of 
wetting after five minutes). Sterile Schirmer test strips were utilized (TearFlo, HUB Pharmaceuticals, Plymouth, MI, USA). Corneal contact was avoided in order to limit reflex lacrimal secretion, and the strips were immediately stored in $-80^{\circ} \mathrm{C}$ for the follow up analysis of total tear IgE.

IgE Analysis: Schirmer strips from the right eye of each patient were used. The Schirmer strips were defrosted and total tear proteins were eluted from the wetted area of the strip into $30 \mu \mathrm{L}$ BSS by first vortexing for $10 \mathrm{~s}$, followed by gentle shaking for $1 \mathrm{~h}$ at room temperature, followed by an additional vortexing for $10 \mathrm{~s}$. The sample was centrifuged for $1 \mathrm{~min}$, and the solution was removed and kept on ice. An additional $30 \mu \mathrm{L}$ BSS was added to the strips, and the samples were processed as above. The eluates were pooled and then stored at $-80^{\circ} \mathrm{C}$ until analysis.

ELISA was performed on the eluted tear samples using Human IgE ELISAPRO kit (MABTECH INC West Street Cincinnati, OH, USA), following the manufacturer's directions. Each eluted sample was diluted to a final volume of $200 \mu \mathrm{L}$ using BSS, and equivalent volumes of $100 \mu \mathrm{L}$ of each sample were tested in duplicate. These precautionary volume adjustments were performed to ensure standardization of tear fluid volumes in the samples. Negative controls (assay background control and blanks) were included to measure background signals from the plate and the positive control was a standard IgE stock solution provided with the kit. The limit of total tear IgE detection was $0.069 \mathrm{ng} / \mathrm{mL}$. The ELISA was quantified using a microplate reader at $450 \mathrm{~nm}$ (BMG Labtech Omega microplate reader). The data were fit to a 4-parameter standard curve, and the average of each sample was calculated after subtracting the blank from the standard for each run (blank corrected values). We chose not to measure allergen-specific tear IgE because potential allergens were unknown at the time of analysis.

Statistical Analysis: All statistical analyses were performed using STATA Version 14 (STATA Inc., 2014). Descriptive analyses were employed to examine study variables. We examined the contribution of independent variables on total tear IgE, both as a continuous variable using linear regression and as an ordinal variable using ordinal logistic regression (function ologit) and treating IgE level below the detection limit as the base. For the categorical analysis, we binned our subjects into 3 groups: $<0.69 \mathrm{ng} / \mathrm{mL}$ (non-detectable (ND)), $\leq 1 \mathrm{ng} / \mathrm{mL}$ (Low), and $>1 \mathrm{ng} / \mathrm{mL}$ (High). We chose $1 \mathrm{ng} / \mathrm{mL}$ $(0.417 \mathrm{IU} / \mathrm{mL})$ as the cutoff between Low and High IgE status based on prior studies [27-29].

\section{Results}

\subsection{Study Population}

A total of 75 individuals with DE symptoms and/or signs, but without a diagnosis of AC were included. Mean age was 66.2 years \pm 7.7 , and the majority of subjects were male $(87 \%)$, white $(60 \%)$, and non-Hispanic (67\%). Sixty-two individuals had dry eye symptoms (DEQ5 $\geq 6$ ), and 75 had one or more signs of DE. Mean DE symptoms (via DEQ5) were in the moderate range (11.04 \pm 5.32$)$, and most individuals had evaporative DE (TBUT $\leq 8 \mathrm{~s}, 54.7 \%$ ) with adequate tear production (Schirmer score $\geq 8$, 91.9\%). Fifty-seven individuals (76\%) had detectable IgE levels in their tears ( $\geq 0.069 \mathrm{ng} / \mathrm{mL})$ and 13 $(17.3 \%)$ had High total tear IgE, defined as a value $>1 \mathrm{ng} / \mathrm{mL}$ based on prior literature [27-29] (Table 1). 
Table 1. Descriptive statistics of Miami VA Cohort recruited during 2010 and 2011 by IgE status: \# of patients (\% of patients).

\begin{tabular}{|c|c|c|c|c|}
\hline & $\begin{array}{c}\text { IgE Level Not } \\
\text { Detectable (ND) }\end{array}$ & $\begin{array}{l}\text { Low IgE Level } \\
(\leq 1 \mathrm{ng} / \mathrm{mL})\end{array}$ & $\begin{array}{l}\text { High IgE Level } \\
\text { (>1 ng/mL) }\end{array}$ & $p$-Value \\
\hline IgE status & $18(24.0 \%)$ & $44(58.7 \%)$ & $13(17.3 \%)$ & \\
\hline \multicolumn{4}{|c|}{ Race } & 0.97 \\
\hline White & $12(24.0 \%)$ & $29(58.0 \%)$ & $9(18.0 \%)$ & \\
\hline Black & $6(24.0 \%)$ & $15(60.0 \%)$ & $4(16.0 \%)$ & \\
\hline \multicolumn{4}{|c|}{ Birth place } & 0.71 \\
\hline Florida & $2(20.0 \%)$ & $6(60.0 \%)$ & $2(20.0 \%)$ & \\
\hline US outside FL & $8(20.0 \%)$ & $24(60.0 \%)$ & $8(20.0 \%)$ & \\
\hline Outside US & $7(36.8 \%)$ & $9(47.4 \%)$ & $3(15.8 \%)$ & \\
\hline \multicolumn{5}{|c|}{ Psychiatric status } \\
\hline Depression symptoms & $3(21.4 \%)$ & $8(57.1 \%)$ & $3(21.4 \%)$ & 0.89 \\
\hline PTSD & $2(18.2 \%)$ & $7(63.6 \%)$ & $2(18.2 \%)$ & 0.88 \\
\hline \multicolumn{5}{|c|}{ Co-morbidities } \\
\hline Hypertension & $5(26.3 \%)$ & $11(57.9 \%)$ & $3(15.8 \%)$ & 0.30 \\
\hline Sleep apnea & $6(40.0 \%)$ & $7(46.7 \%)$ & $2(13.3 \%)$ & 0.27 \\
\hline Diabetes & $6(28.6 \%)$ & $12(57.1 \%)$ & $3(14.3 \%)$ & 0.81 \\
\hline Thyroid, & $3(33.3 \%)$ & $5(55.6 \%)$ & $1(11.1 \%)$ & 0.73 \\
\hline Osteoarthritis & $10(30.3 \%)$ & $18(54.6 \%)$ & $5(15.2 \%)$ & 0.52 \\
\hline Antihistamine & $7(41.2 \%)$ & $8(47.1 \%)$ & $2(11.8 \%)$ & 0.16 \\
\hline \multicolumn{4}{|c|}{ Pet(s) at home } & $0.003^{* * *}$ \\
\hline No & $14(32.6 \%)$ & $26(60.5 \%)$ & $3(7.0 \%)$ & \\
\hline Yes & $3(11.5 \%)$ & $13(50.0 \%)$ & $10(38.5 \%)$ & \\
\hline \multicolumn{4}{|c|}{ Smoking status } & $0.03^{* *}$ \\
\hline No & $18(25.7 \%)$ & $42(60.0 \%)$ & $10(14.3 \%)$ & \\
\hline Yes & $0(0.0 \%)$ & $2(40.0 \%)$ & $3(60.0 \%)$ & \\
\hline \multicolumn{4}{|c|}{ Second-hand smoking exposure at home } & $0.02^{* *}$ \\
\hline No & $15(23.4 \%)$ & $39(60.9 \%)$ & $10(15.6 \%)$ & \\
\hline Yes & $2(40.0 \%)$ & $0(0.0 \%)$ & $3(60.0 \%)$ & \\
\hline \multicolumn{4}{|c|}{ Season } & $0.03^{* *}$ \\
\hline Off peak (fall \& winter) & $14(31.8 \%)$ & $26(59.1 \%)$ & $4(9.1 \%)$ & \\
\hline Peak (spring \& summer) & $4(12.9 \%)$ & $18(58.1 \%)$ & $9(29.0 \%)$ & \\
\hline \multicolumn{4}{|c|}{ Environmental allergies } & 0.46 \\
\hline No & $14(25.0 \%)$ & $33(58.9 \%)$ & $9(16.1 \%)$ & \\
\hline Yes & $3(23.1 \%)$ & $6(46.2 \%)$ & $4(30.8 \%)$ & \\
\hline \multicolumn{4}{|c|}{ Eczema } & 0.29 \\
\hline No & $17(27.0 \%)$ & $34(54.0 \%)$ & $12(19.1 \%)$ & \\
\hline Yes & $0(0.0 \%)$ & $5(83.3 \%)$ & $1(16.7 \%)$ & \\
\hline \multicolumn{4}{|c|}{ Ventilation by opening windows } & 0.11 \\
\hline a week/never & $8(24.2 \%)$ & $16(48.5 \%)$ & $9(27.3 \%)$ & \\
\hline more than twice/week & $10(23.8 \%)$ & $28(66.7 \%)$ & $4(9.5 \%)$ & \\
\hline
\end{tabular}




\subsection{DE and Total Tear IgE}

Total tear IgE levels were not found to correlate with DE measures, both when considering symptoms and signs of disease. For example, High tear IgE was observed in $17 \%$ of individuals with negligible DE symptoms (DEQ5 < 6), 27\% of individuals with mild-moderate symptoms (DEQ5 $\geq 6$ and $<12$ ), and $11 \%$ of individuals with severe symptoms (DEQ5 $\geq 12$ ) (Table 2). While no significant correlations between total tear IgE levels and DE signs were observed, there was a positive trend between total tear IgE and tear production. Patients with ND IgE had the lowest mean Schirmer scores (9.9 $\pm 1.3 \mathrm{~mm} / 5 \mathrm{~min}, 95 \%$ confidence interval (CI) 8.6-11.2); those with Low IgE had higher scores (12.4 $\pm 1.0 \mathrm{~mm} / 5 \mathrm{~min}, 95 \%$ CI 11.4-13.4); and those with High IgE had the highest scores (13.6 $\pm 1.7 \mathrm{~mm} / 5 \mathrm{~min}, 95 \%$ CI 12.9-15.3) (Table 2).

Table 2. Dry eye parameters of Miami VA Cohort recruited during 2010 and 2011 by IgE status: Mean (standard deviation; \# of patients).

\begin{tabular}{|c|c|c|c|c|}
\hline \multirow[b]{2}{*}{ Dry Eye Parameter } & \multicolumn{3}{|c|}{ IgE Status } & \multirow[b]{2}{*}{$p$-Value } \\
\hline & $\begin{array}{c}\text { IgE Level Not } \\
\text { Detectable (ND) }\end{array}$ & $\begin{array}{l}\text { Low IgE Level } \\
(\leq 1 \mathrm{ng} / \mathrm{mL})\end{array}$ & $\begin{array}{l}\text { High IgE Level } \\
(>1 \mathrm{ng} / \mathrm{mL})\end{array}$ & \\
\hline TBUT (s) & $\begin{array}{c}8.7 \\
(1.1 ; 18)\end{array}$ & $\begin{array}{c}7.3 \\
(0.7 ; 44)\end{array}$ & $\begin{array}{c}9.0 \\
(1.3 ; 13)\end{array}$ & 0.37 \\
\hline Osmolarity (mOsm/L) & $\begin{array}{c}308.9 \\
(2.8 ; 17) \\
\end{array}$ & $\begin{array}{c}307.4 \\
(1.7 ; 44)\end{array}$ & $\begin{array}{c}311.2 \\
(2.6 ; 13)\end{array}$ & 0.81 \\
\hline Schirmer wetting length $(\mathrm{mm} / 5 \mathrm{~min})$ & $\begin{array}{c}9.9 \\
(1.3 ; 18)\end{array}$ & $\begin{array}{c}12.4 \\
(1.0 ; 44)\end{array}$ & $\begin{array}{c}13.6 \\
(1.7 ; 13)\end{array}$ & 0.23 \\
\hline Corneal Staining Score & $\begin{array}{c}1.27 \\
(1.01 ; 18)\end{array}$ & $\begin{array}{c}1.11 \\
(1.08 ; 44)\end{array}$ & $\begin{array}{c}0.69 \\
(0.85 ; 13)\end{array}$ & 0.28 \\
\hline DEQ5 Score & $\begin{array}{c}10.7 \\
(1.3 ; 18)\end{array}$ & $\begin{array}{c}11.5 \\
(0.8 ; 44)\end{array}$ & $\begin{array}{c}9.4 \\
(1.5 ; 13)\end{array}$ & 0.39 \\
\hline
\end{tabular}

TBUT = tear break up time; DEQ5 = Dry Eye Questionnaire-5.

\subsection{Total Tear IgE and Home Exposures}

The presence of environmental allergens and/or irritants inside the home positively associated with detectable total tear IgE levels (Table 1). Specifically, individuals with pet(s) at home had a higher frequency of High IgE (38.5\% vs. $7.0 \%$ ) compared to those with no pet(s) ( $p=0.003)$. Likewise, individuals who smoked ( $60 \%$ vs. $14.3 \%, p=0.027$ ) or were exposed to second hand smoke at home $(60 \%$ vs. $15.6 \%, p=0.015)$ had a higher frequency of High IgE compared to individuals not exposed to smoke at home. Finally, tear collection during local allergy season (spring and summer) associated with a higher frequency of High IgE $(29.0 \%$ vs. $9.1 \%)$ and lower frequency of ND IgE $(12.9 \%$ vs. $31.8 \%)$ compared to samples collected during fall and winter $(p=0.032)$ (Table 1). These findings were confirmed via multivariable analyses, in which total tear IgE (as a continuous variable) and total tear IgE categories (ND, Low, and High) were examined separately, adjusting for covariables including age, birthplace, smoking status, DE measures, and pet(s) (Table 3). Smoking status (OR $=38.57, p=0.008$ ) and pet(s) in home (OR $=11.54, p=0.002)$ showed significant association both with total tear IgE at a $\log$ scale and total tear IgE categories. Measurement during spring or summer (local peak allergy seasons) ( $\mathrm{OR}=3.94, p=0.028$ ) was a significant risk factor, while birthplace outside the US was a significant protective factor $(\mathrm{OR}=0.29, p=0.010)$ based on categorical analyses. In the analysis of total tear IgE as a continuous variable, patients below the limit of detection were excluded, restricting the analysis to 52 patients. IgE levels among smokers and patients with a pet at home were $2.86(p=0.033)$ and $2.16(p=0.049)$ times higher than among non-smokers and patients without a pet, respectively. Even exposure to second-hand smoke had a significant positive association with total tear IgE levels $(p<0.01)$. 
Table 3. Association of the selected covariables with IgE levels and IgE categories.

\begin{tabular}{|c|c|c|}
\hline Selected Covariables & $\begin{array}{c}\text { IgE Level as Expressed by } \\
\log _{\mathrm{e}}(\operatorname{IgE}(\mathrm{ng} / \mathrm{mL}))^{\mathrm{a}}\end{array}$ & $\begin{array}{c}\text { IgE Categories } \\
\text { Odds Ratio }\end{array}$ \\
\hline \multirow{2}{*}{ Age } & 0.00992 & 0.98 \\
\hline & $(-0.0375-0.0574)$ & $(0.89-1.09)$ \\
\hline \multirow{2}{*}{ Birth place } & $-0.430 *$ & $0.29 * *$ \\
\hline & $(-0.907-0.0476)$ & $(0.11-0.75)$ \\
\hline \multirow{2}{*}{ Smoking status } & $1.046^{* *}$ & $38.57^{* *}$ \\
\hline & $(0.0901-2.002)$ & $(1.90-783.22)$ \\
\hline \multirow{2}{*}{ Tear break up time (second) } & -0.00054 & 0.93 \\
\hline & $(-0.0684-0.0673)$ & $(0.82-1.06)$ \\
\hline \multirow{2}{*}{ Schirmer length (mm) } & -0.032 & 1.03 \\
\hline & $(-0.0996-0.0357)$ & $(0.91-1.17)$ \\
\hline \multirow{2}{*}{ Osmolarity (mOsmol/1) } & -0.00056 & 1.00 \\
\hline & $(-0.0402-0.0391)$ & $(0.93-1.08)$ \\
\hline \multirow{2}{*}{ Allergy status $(0=$ no, $1=$ yes $)$} & 0.366 & 2.24 \\
\hline & $(-0.507-1.238)$ & $(0.51-9.89)$ \\
\hline \multirow{2}{*}{ Eczema status $(0=$ no, $1=$ yes $)$} & 0.187 & 1.48 \\
\hline & $(-0.772-1.146)$ & $(0.25-8.76)$ \\
\hline \multirow{2}{*}{ Pet at home $(0=$ no, $1=$ yes $)$} & $0.777^{* *}$ & $11.54^{* * *}$ \\
\hline & $(0.00193-1.552)$ & $(2.47-53.79)$ \\
\hline \multirow{2}{*}{ Smoker at home other than the patient $(0=$ no, $1=$ yes $)$} & $1.093^{* * *}$ & 1.44 \\
\hline & $(0.351-1.835)$ & $(0.04-57.65)$ \\
\hline \multirow{2}{*}{$\begin{array}{c}\text { Ventilation by opening windows } \\
(0=>\text { week or never } 1 \text { = more than once/week })\end{array}$} & -0.29 & 0.57 \\
\hline & $(-0.986-0.406)$ & $(0.19-1.70)$ \\
\hline \multirow{2}{*}{ Season $(0=$ fall \& winter; $1=$ otherwise $)$} & 0.38 & $3.94^{* *}$ \\
\hline & $(-0.397-1.157)$ & $(1.04-14.91)$ \\
\hline \multirow{2}{*}{ Constant } & -0.503 & \\
\hline & $(-13.76-12.76)$ & \\
\hline Observations & 52 & 68 \\
\hline R-squared & 0.322 & NA \\
\hline
\end{tabular}

Robust 95\% confidence interval in parentheses; ${ }^{* * *} p<0.01,{ }^{* *} p<0.05,{ }^{*} p<0.1$. a $=\operatorname{IgE}$ was skewed, therefore, $\operatorname{IgE}$ $(\mathrm{ng} / \mathrm{mL})$ was fitted at natural log scale. $\mathrm{b}=\mathrm{IgE}$ was categorized into three groups: $0=$ not detected; $1 \leq 1 \mathrm{ng} / \mathrm{mL}$ and $2>1 \mathrm{ng} / \mathrm{mL}$; ordinal logistic regression was used to fit the IgE categories. NA = Not applicable.

\section{Discussion}

We found that a majority of individuals with clinical features of DE but no diagnosis of AC had detectable total tear IgE levels. Seventeen percent had High levels, defined as $>1 \mathrm{ng} / \mathrm{mL}$. Individuals with High tear IgE levels were more likely to be exposed to allergens and irritants in their home environment. Our data provide indirect evidence that some individuals with symptoms and/or signs of DE have an allergic component underlying their disease. However, we did not find that one specific manifestation of $\mathrm{DE}$ associated with tear $\mathrm{IgE}$, as levels were distributed equally amount the different $\mathrm{DE}$ measures. The only trend noted was between Schirmer score and IgE levels, with high tear production positively associating with total tear IgE. Interestingly, elevated tear production has been well described in $\mathrm{AC}[30]$.

Overall, the mean total tear IgE level (for those with detectable levels) in our population was $0.363 \mathrm{IU} / \mathrm{mL}(0.873 \mathrm{ng} / \mathrm{mL})$, which is higher than prior reports from healthy controls $(0.058 \mathrm{IU} / \mathrm{mL}$; 95\% CI 0.012-0.287), but lower than what has been reported in patients with AC (5.259 IU $/ \mathrm{mL} ; 95 \%$ CI 0.053-523.219) [24,31-33]. This is not surprising, as none of our subjects had a diagnosis of AC, but points to a possible subclinical component of allergy in a portion of our patients. However, it is 
important to remember that elevations in total serum and/or tear IgE are not specific for allergy, so we cannot say definitively that undiagnosed allergy was behind the tear IgE elevations we observed. A range of parasitic, helminthic, and viral infections, tuberculosis, eosinophilic granulomatosis with polyangitis, certain lymphomas and myelomas, various autoimmune diseases, and bone marrow transplantation may all result in increased total $\operatorname{IgE}$ in serum and perhaps in tears. Although we excluded individuals with known systemic confounders of allergy, it is possible that some individuals had undiagnosed disease.

There is biologic plausibility for the observed relationships between our noted exposures and ocular surface parameters. Pet dander is already known to drive several IgE-mediated conditions, including AC [32], so it is not surprising that exposure posed an increased risk of having high total tear IgE. Increased total tear IgE levels in spring and summer are likely due to greater exposure to outdoor aeroallergens, which are elevated locally at those times of year [34]. Interestingly, we found tobacco exposure was positively correlated with total tear IgE as well, even though smoke is not known to cause IgE-mediated sensitization. Tobacco smoke is an irritant associated with decreased desmosome connections in the mammalian conjunctival epithelium [35]. It is plausible that such histopathologic changes result in increased allergen penetration at the ocular surface. This is supported by the fact that exposure exacerbates AC [36], with one study citing tobacco smoke as a trigger for $6.1 \%$ of AC patients $(n=2817)$ [8]. Moreover, tobacco smoke has been shown to modulate IgE expression in murine models of allergic disease [37,38].

As with all studies, our findings must be considered in light of the study limitations. First, there are technical concerns in total tear IgE measurement, as sample volumes differed between subjects with variable Schirmer wetting lengths. We attempted to mitigate this limitation by normalizing tear fluid volumes for analysis and then by controlling for tear volume in the multivariable analysis. Indeed, Schirmer length did not significantly associate with IgE, suggesting that his was not a confounding factor in our data. Second, tear IgE levels may be elevated for reasons other than ocular allergy. For example, it is possible that some of our cohort had increased conjunctival vessel permeability secondary to ocular surface inflammation, which could lead to increased total tear protein and IgE content. As such, future studies are needed that evaluate other potential biomarkers of allergy, such as trypase [39], eosinophil cationic protein, interleukins 4, 5, and 13, and matrix metalloproteinase-9 [14], and compare their levels to IgE. It is also possible that applying Schirmer strips contributed to a local inflammatory response that changed the protein milieu of tears. However, we believe that the $5 \mathrm{~min}$ duration of exposure would be unlikely to capture a change in protein expression. An alternative tear collection method would have been to use glass capillary tubes [27]. However, this methodology has its own limitation, as it often requires a wash to remove enough tears, especially in individuals with low tear volume or conjunctival chalasis. Third, samples were stored from 6-7 years prior to analysis and it is unknown if IgE was degraded during storage. Fortunately, there was no relationship between storage length and IgE levels. Fourth, the population studied was predominately older male veterans, and DE symptoms and signs were assessed with a set protocol. Future studies in diverse populations and with more robust protocols will be needed to increase generalizability. Finally, we determined exposures by history and not by direct measurements. This is an important avenue of future study, and may be more relevant when measuring allergen-specific tear and serum IgE, because specific exposures in our population were unknown prior to data collection.

Despite these limitations, our study findings suggest that a proportion of individuals with clinical features of DE have an underlying component of ocular allergy. While it is not known if tear IgE levels will be the best biomarker to identify these patients, we found several modifiable exposures associated with total tear IgE levels in a heterogeneous group of individuals without a formal AC diagnosis. Identification of such exposures is crucial for the development of preventative and targeted interventions that are more cost effective and less risky than traditional therapies. Future studies, in diverse and well defined populations (such as those with data on skin testing), will be needed to clarify the role of IgE as a biomarker of allergy in individuals with DE. 
Author Contributions: The individual contributions of the authors are as follows: Conceptualization and methodology, A.G., N.K.; investigation D.T., C.L., P.C., A.H.; formal analysis N.K.; funding acquisition A.G., N.K.; project administration A.G., H.D.; supervision A.G., N.K.; visualization H.D., N.K.; writing-original draft C.L., P.C., H.D.; writing-review \& editing H.D., D.T., A.G.

Funding: This research was funded by the Department of Veterans Affairs, Veterans Health Administration, Office of Research and Development, Clinical Sciences Research EPID-006-15S (Galor), R01EY026174 (Kumar and Galor), NIH Center Core Grant P30EY014801 and Research to Prevent Blindness Unrestricted Grant. The authors have no proprietary or commercial interest in any materials discussed in this article. The authors note that the contents of this study do not represent the views of the Department of Veterans Affairs or the United States Government. Contents of this manuscript were presented at the University of Miami 3rd Annual Climate and Health Symposium, 5/11/19, Miami, FL.

Conflicts of Interest: The authors declare no conflict of interest.

\section{Appendix A}

\section{VA Dry Eye and Home Environment Survey:}

\section{A. Demographics}

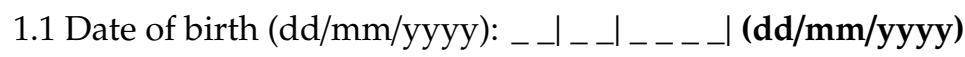

1.2 Were you born in

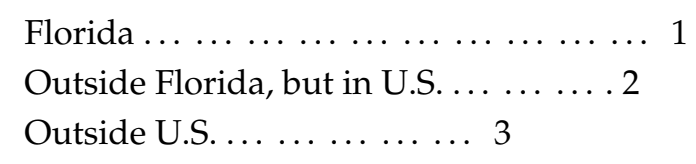

1.3 Current residential address: current street address, city, zip code:

Street Address

Zip Code: City:

1.4 What best describes your home from one of the following?

○ Single family home (e.g., a house) ......... 1

$\bigcirc \quad$ Multi-family building (e.g., apartment or condominium) $\ldots \ldots .2$

○ Mobile home ..... 3

$\bigcirc \quad$ Other... 4

- Don't know/not sure... 5

- Decline to answer....6

1.5 What floor do you live on?

Ground floor (count first floor as the ground floor) ..... 1

Second floor .............. 2

Higher than second floor $\ldots \ldots \ldots \ldots \ldots \ldots \ldots$

1.5a On what floor of the home is your bed room? DO NOT ask this question if response to 1.5 is "Ground Floor"

(XX - two digit response)

1.6 What floor type do you have throughout your home?

$\bigcirc \quad$ Titles (ceramic, marble, travertine or any other stone) ..... 1

Wood $\ldots \ldots \ldots \ldots \ldots \ldots \ldots . \ldots \ldots$

$\bigcirc \quad$ Carpet.............................. 3

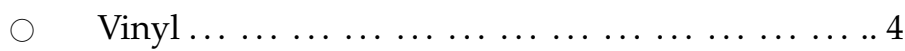

$\bigcirc \quad$ Mixed - carpet in bedroom and tiles/vinyl/wood in the rest of home ... 5

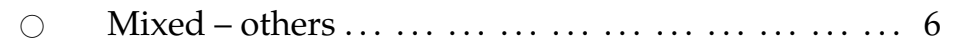


Do not know $\ldots \ldots \ldots \ldots \ldots \ldots \ldots \ldots \ldots \ldots \ldots \ldots \ldots$

1.7 Do you have central air conditioning (AC)?

YES $\ldots \ldots \ldots \ldots \ldots \ldots \ldots \ldots \ldots$

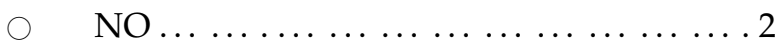

○ $\quad$ DON'T KNOW ................. . 99

If response to question "1.7" is YES then ask "1.7a"

1.7a How often do you change your air filter?

$\bigcirc \quad$ Every month $\ldots \ldots \ldots \ldots \ldots \ldots 1$

$\bigcirc \quad$ Every 3 months ............. 2

$\bigcirc \quad$ Once a year ................ 3

$\bigcirc \quad$ Never.................... 4

1.8 Do you run air purifier?

$\bigcirc \quad \mathrm{YES} \ldots \ldots \ldots \ldots \ldots \ldots \ldots \ldots \ldots \ldots$

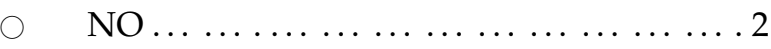

$\bigcirc \quad$ DON'T KNOW ................... . .99

1.9 Do you run dehumidifier?

$\bigcirc \quad \mathrm{YES} \ldots \ldots \ldots \ldots \ldots \ldots \ldots \ldots \ldots \ldots$

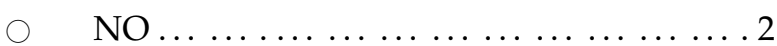

$\bigcirc \quad$ DON'T KNOW ...................99

2.0 Do you often use humidifier?

YES $\ldots \ldots \ldots \ldots \ldots \ldots \ldots \ldots \ldots \ldots$

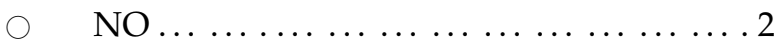

○ DON'T KNOW ................

2.1 What temperature $\left({ }^{\circ} \mathrm{F}\right)$ do you keep indoors? (degree F).

2.2 What relative humidity (\%) do you keep indoors?

2.3 Do you see any signs of fungus and/or mold around your air vents or elsewhere, such as bathroom, kitchen or shower in the home?

$\bigcirc \quad \mathrm{YES} \ldots \ldots \ldots \ldots \ldots \ldots \ldots \ldots \ldots \ldots \ldots \ldots$

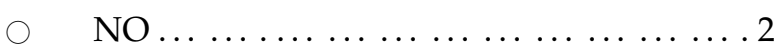

○ DON'T KNOW ................. . .99

2.4 How often do you open your windows for ventilation?

○ Never.......................

$\bigcirc \quad 1-2 /$ month $\ldots \ldots \ldots \ldots \ldots \ldots \ldots .2$

$\bigcirc \quad 1-2 /$ week ...................... 3

$\bigcirc \quad$ Everyday $\ldots \ldots \ldots \ldots \ldots \ldots \ldots \ldots \ldots$

2.5 Does it ever smell moldy (or musty) inside your home?

YES ....................... 1

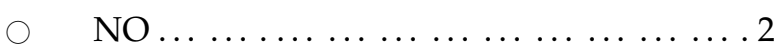


DON'T KNOW $\ldots \ldots \ldots \ldots \ldots \ldots . . .99$

2.6 Do you have any germicidal air purification system, such as ultraviolet-C, in your air condition system?

$\bigcirc \quad$ YES $\ldots \ldots \ldots \ldots \ldots \ldots \ldots \ldots \ldots$

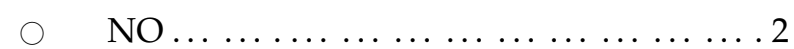

○ DON'T KNOW .................. . . .

2.7 Do you use an air purifier (an electric machine used to clean air) in home?

$\bigcirc \quad$ YES $\ldots \ldots \ldots \ldots \ldots \ldots \ldots \ldots \ldots$

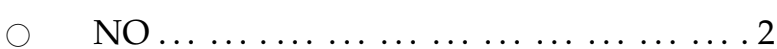

○ DON'T KNOW ................. .99

3.0 Do you currently smoke?

$\bigcirc \quad$ YES $\ldots \ldots \ldots \ldots \ldots \ldots \ldots \ldots \ldots \ldots$

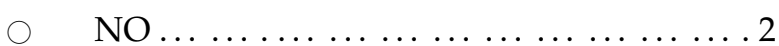

$\circ \quad$ DON'T KNOW ................. . 99

3.1 Does anyone who lives with you in your home smoke?

$\bigcirc \quad$ YES ............................ 1

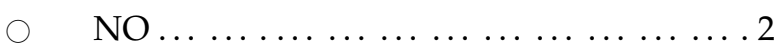

$\bigcirc \quad$ DON'T KNOW .................... . 99

3.2 Do you have any pets at home?

$\bigcirc \quad$ YES $\ldots \ldots \ldots \ldots \ldots \ldots \ldots \ldots \ldots$

○ $\quad \mathrm{NO} \ldots \ldots \ldots \ldots \ldots \ldots \ldots \ldots \ldots \ldots 2$

○ DON'T KNOW ..................

B. Current Dry Eye Symptoms (2-4 questions max)

4.0

4.1

4.2

4.4

C. Other health related questions

5. Has any doctor ever told you that you have environmental allergies?

Y YES ....................... 1

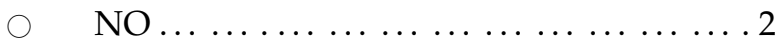

○ DON'T KNOW $\ldots \ldots \ldots \ldots \ldots \ldots . . . .99$

5.1 If response to question 5 is "YES" then ask this. Are you allergic to any of the following?

- $\quad$ Mold $\ldots \ldots \ldots \ldots \ldots \ldots \ldots \ldots$

- $\quad$ Pollens $\ldots \ldots \ldots \ldots \ldots \ldots \ldots \ldots . \ldots \ldots$

- $\quad$ Pets ................... 3

- $\quad$ Foods .....................4

- $\quad$ Don't know ...................... 5

5.2 Has a doctor or other health professional ever told you that you have eczema?

$\bigcirc \quad$ YES .......................... 1

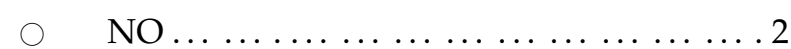

$\bigcirc \quad$ DON'T KNOW ................... . 99 


\section{References}

1. Bron, A.J.; De Paiva, C.S.; Chauhan, S.K.; Bonini, S.; Gabison, E.E.; Jain, S.; Knop, E.; Markoulli, M.; Ogawa, Y.; Perez, V.; et al. TFOS DEWS II pathophysiology report. Ocul. Surf. 2017, 15, 438-510. [CrossRef] [PubMed]

2. Craig, J.P.; Nichols, K.K.; Akpek, E.K.; Caffery, B.; Dua, H.S.; Joo, C.-K.; Liu, Z.; Nelson, J.D.; Nichols, J.J.; Tsubota, K.; et al. TFOS DEWS II Definition and Classification Report. Ocul. Surf. 2017, 15, $276-283$. [CrossRef] [PubMed]

3. Stapleton, F.; Alves, M.; Bunya, V.Y.; Jalbert, I.; Lekhanont, K.; Malet, F.; Na, K.S.; Schaumberg, D.; Uchino, M.; Vehof, J.; et al. TFOS DEWS II Epidemiology Report. Ocul. Surf. 2017, 15, 334-365. [CrossRef] [PubMed]

4. Farrand, K.F.; Fridman, M.; Stillman, Ö.I.; Schaumberg, D.A. Prevalence of Diagnosed Dry Eye Disease in the United States Among Adults Aged 18 Years and Older. Am. J. Ophthalmol. 2017, 182, 90-98. [CrossRef] [PubMed]

5. The Epidemiology of Dry Eye Disease: Report of the Epidemiology Subcommittee of the International Dry Eye WorkShop (2007). Ocul. Surf. 2007, 5, 93-107. [CrossRef]

6. Van Tilborg, M.M.; Murphy, P.J.; Evans, K.S. Impact of Dry Eye Symptoms and Daily Activities in a Modern Office. Optom. Vis. Sci. 2017, 94, 688-693. [CrossRef]

7. Gomes, P.J. Trends in prevalence and treatment of ocular allergy. Curr. Opin. Allergy Clin. Immunol. 2014, 14, 451-456. [CrossRef]

8. Leonardi, A.; Piliego, F.; Castegnaro, A.; Lazzarini, D.; Valerio, A.L.G.; Mattana, P.; Fregona, I. Allergic conjunctivitis: A cross-sectional study. Clin. Exp. Allergy 2015, 45, 1118-1125. [CrossRef]

9. Blaiss, M.S.; Hammerby, E.; Robinson, S.; Kennedy-Martin, T.; Buchs, S. The burden of allergic rhinitis and allergic rhinoconjunctivitis on adolescents: A literature review. Ann. Allergy Asthma Immunol. 2018, 121, 43-52e3. [CrossRef]

10. Galor, A.; Small, L.; Feuer, W.; Levitt, R.C.; Sarantopoulos, K.D.; Yosipovitch, G. The Relationship Between Ocular Itch, Ocular Pain, and Dry Eye Symptoms (An American Ophthalmological Society Thesis). Trans. Am. Ophthalmol. Soc. 2017, 115, T5.

11. Hom, M.M.; Nguyen, A.L.; Bielory, L. Allergic conjunctivitis and dry eye syndrome. Ann. Allergy Asthma Immunol. 2012, 108, 163-166. [CrossRef] [PubMed]

12. Fujishima, H.; Toda, I.; Shimazaki, J.; Tsubota, K. Allergic conjunctivitis and dry eye. Br. J. Ophthalmol. 1996, 80, 994-997. [CrossRef] [PubMed]

13. Stern, M.E.; Pflugfelder, S.C. Inflammation in dry eye. Ocul. Surf. 2004, 2, 124-130. [CrossRef]

14. Leonardi, A. Allergy and allergic mediators in tears. Exp. Eye Res. 2013, 117, 106-117. [CrossRef] [PubMed]

15. Villani, E.; Rabbiolo, G.; Nucci, P. Ocular allergy as a risk factor for dry eye in adults and children. Curr. Opin. Allergy Clin. Immunol. 2018, 18, 398-403. [CrossRef]

16. Dermer, H.; Galor, A.; Hackam, A.S.; Mirsaeidi, M.; Kumar, N. Impact of seasonal variation in meteorological conditions on dry eye severity. Clin. Ophthalmol. 2018, 12, 2471-2481. [CrossRef]

17. Meltzer, E.O.; Farrar, J.R.; Sennett, C. Findings from an Online Survey Assessing the Burden and Management of Seasonal Allergic Rhinoconjunctivitis in US Patients. J. Allergy Clin. Immunol. Pr. 2017, 5, 779-789.e6. [CrossRef]

18. Segundo, G.R.S.; Sopelete, M.C.; Terra, S.A.; Pereira, F.L.; Justino, C.M.; Silva, D.A.D.O.; Taketomi, E.A.; Sopelete, M.C.S. Diversity of allergen exposure: Implications for the efficacy of environmental control. Braz. J. Otorhinolaryngol. 2009, 75, 311-316. [CrossRef]

19. Gomes, P.J.; Ousler, G.W.; Welch, D.L.; Smith, L.M.; Coderre, J.; Abelson, M.B. Exacerbation of signs and symptoms of allergic conjunctivitis by a controlled adverse environment challenge in subjects with a history of dry eye and ocular allergy. Clin. Ophthalmol. 2013, 7, 157-165. [CrossRef]

20. Galor, A.; Kumar, N.; Feuer, W.; Lee, D.J. Environmental Factors Affect the Risk of Dry Eye Syndrome in a United States Veteran Population. Ophthalmol. 2014, 121, 972-973.e1. [CrossRef]

21. Kim, M.; Oh, J.-H.; Park, C.Y.; Lee, S.W. Dry Eye Disease and Allergic Conditions: A Korean Nationwide Population-Based Study. Am. J. Rhinol. Allergy 2016, 30, 397-401. [CrossRef] [PubMed]

22. Platts-Mills, T.A.E.; Schuyler, A.J.; Erwin, E.A.; Commins, S.P.; Woodfolk, J.A. IgE in the diagnosis and treatment of allergic disease. J. Allergy Clin. Immunol. 2016, 137, 1662-1670. [CrossRef] [PubMed]

23. Platts-Mills, T.A.E. The Role of Immunoglobulin E in Allergy and Asthma. Am. J. Respir. Crit. Care Med. 2001, 164, 1-5. [CrossRef] [PubMed] 
24. Nomura, K.; Takamura, E. Tear IgE concentrations in allergic conjunctivitis. Eye 1998, 12, 296-298. [CrossRef] [PubMed]

25. Chalmers, R.L.; Begley, C.G.; Caffery, B. Validation of the 5-Item Dry Eye Questionnaire (DEQ-5): Discrimination across self-assessed severity and aqueous tear deficient dry eye diagnoses. Contact Lens Anterior Eye 2010, 33, 55-60. [CrossRef] [PubMed]

26. Methodologies to Diagnose and Monitor Dry Eye Disease: Report of the Diagnostic Methodology Subcommittee of the International Dry Eye WorkShop (2007). Ocul. Surf. 2007, 5, 108-152. [CrossRef]

27. Aalders-Deenstra, V.; Kok, P.T.; Bruynzeel, P.L. Measurement of total IgE antibody levels in lacrimal fluid of patients suffering from atopic and non-atopic eye disorders. Evidence for local IgE production in atopic eye disorders? Br. J. Ophthalmol. 1985, 69, 380-384. [CrossRef]

28. Baudouin, C.; Bourcier, T.; Brignole, F.; Bertel, F.; Moldovan, M.; Goldschild, M.; Goguel, A. Correlation between tear IgE levels and HLA-DR expression by conjunctival cells in allergic and nonallergic chronic conjunctivitis. Graefe's Arch. Clin. Exp. Ophthalmol. 2000, 238, 900-904. [CrossRef]

29. Agha, F.; Sadaruddin, A.; Abbas, S.; Ali, S.M. Serum IgE levels in patients with allergic problems and healthy subjects. J. Pak. Med. Assoc. 1997, 47, 166-169.

30. Khurana, A.K.; Moudgil, S.S.; Parmar, I.P.; Ahluwalia, B.K. Tear film flow and stability in acute and chronic conjunctivitis. Acta Ophthalmol. 1987, 65, 303-305. [CrossRef]

31. Mimura, T.; Usui, T.; Yamagami, S.; Miyai, T.; Amano, S. Relationship Between Total Tear IgE and Specific Serum IgE in Autumnal Allergic Conjunctivitis. Cornea 2013, 32, 14-19. [CrossRef] [PubMed]

32. Mimura, T.; Yamagami, S.; Kamei, Y.; Goto, M.; Matsubara, M. Specific IgE in Tear Fluid and Features of Allergic Conjunctivitis. Curr. Eye Res. 2013, 38, 917-925. [CrossRef] [PubMed]

33. Hoffmann-Sommergruber, K.; Ferreira, F.D.; Ebner, C.; Barisani, T.; Korninger, L.; Scheiner, D.K.O.; Baumgartner, I.; Ferreira, F. Detection of allergen-specific IgE in tears of grass pollen-allergic patients with allergic rhinoconjunctivitis. Clin. Exp. Allergy 1996, 26, 79-87. [CrossRef] [PubMed]

34. Phillips, J.F.; Jelks, M.L.; Lockey, R.F. Important Florida botanical aeroallergens. Allergy Asthma Proc. 2010, 31, 337-340. [CrossRef]

35. Avunduk, A.M.; Avunduk, M.C.; Evirgen, O.; Yardimci, S.; Taştan, H.; Güven, C.; Cetinkaya, K. Histopathological and ultrastructural examination of the rat conjunctiva after exposure to tobacco smoke. Ophthalmol. 1997, 211, 296-300. [CrossRef] [PubMed]

36. Akil, H.; Celik, F.; Ulas, F.; Kara, I.S. Dry Eye Syndrome and Allergic Conjunctivitis in the Pediatric Population. Middle East Afr. J. Ophthalmol. 2015, 22, 467-471. [CrossRef]

37. Seymour, B.W.P.; Peake, J.L.; Pinkerton, K.E.; Kurup, V.P.; Gershwin, L.J. Second-hand Smoke Increases Nitric Oxide and Alters the IgE Response in a Murine Model of Allergic Aspergillosis. Clin. Dev. Immunol. 2005, 12, 113-124. [CrossRef]

38. Robbins, C.S.; Pouladi, M.A.; Fattouh, R.; Dawe, D.E.; Vujicic, N.; Richards, C.D.; Jordana, M.; Inman, M.D.; Stampfli, M.R. Mainstream cigarette smoke exposure attenuates airway immune inflammatory responses to surrogate and common environmental allergens in mice, despite evidence of increased systemic sensitization. J. Immunol. 2005, 175, 2834-2842. [CrossRef]

39. Francis, A.; Fatovich, D.M.; Arendts, G.; Macdonald, S.P.; Bosio, E.; Nagree, Y.; Mitenko, H.M.; Brown, S.G. Serum mast cell tryptase measurements: Sensitivity and specificity for a diagnosis of anaphylaxis in emergency department patients with shock or hypoxaemia. Emerg. Med. Australas. 2018, 30, 366-374. [CrossRef] [PubMed]

(C) 2019 by the authors. Licensee MDPI, Basel, Switzerland. This article is an open access article distributed under the terms and conditions of the Creative Commons Attribution (CC BY) license (http://creativecommons.org/licenses/by/4.0/). 